\title{
Lactate inhibits hydrolysis of polysaccharide-rich particulate organic waste
}

\author{
Fan Lü ${ }^{\text {a }}$, Pin-Jing He ${ }^{\mathrm{a}, *}$, Li-Ming Shao ${ }^{\mathrm{a}}$, Duu-Jong Lee ${ }^{\mathrm{b}}$ \\ ${ }^{a}$ State Key Laboratory of Pollution Control and Resource Reuse, Tongji University, 1239 Siping Road, Shanghai 200092, PR China \\ ${ }^{\mathrm{b}}$ Department of Chemical Engineering, National Taiwan University, Taipei 10617, Taiwan
}

Received 4 February 2007; received in revised form 29 April 2007; accepted 29 April 2007

Available online 19 June 2007

\begin{abstract}
This work reveals that, at $\mathrm{pH} 5-9$, a lactate level of up to $30 \mathrm{~g}^{-1}$ retarded hydrolysis rates in polysaccharide-rich potato samples. Lactate substantially limited carbohydrate hydrolysis and enhanced the hydrolysis of proteins. Statistical analysis identified the significance of numerous process factors in substrate hydrolysis. At fixed $\mathrm{pH}$, dissociated lactate affected hydrolysis rates more strongly than its molecular counterpart. At a fixed lactate level, an alkaline environment favors carbohydrate hydrolysis; the effect of $\mathrm{pH}$ is secondary. Significant effects of lactate on substrate hydrolysis may be evident in fermenting organic substrates with high carbohydrate content.

(C) 2007 Elsevier Ltd. All rights reserved.
\end{abstract}

Keywords: Hydrolysis; Partial least squares; Acid toxicity; Fermentation; Anaerobic digestion

\section{Introduction}

Substrate hydrolysis reduces the efficiency of anaerobic digestion of particulate organic waste (Mata-Alvarez, 2003; Miron et al., 2000; Sanders et al., 2003; Vavilin et al., 1996). The anaerobic digestion model (ADM) No. 1 model does not consider the inhibitory effects of substrate or the products of substrate hydrolysis (Batstone et al., 2002). However, recent investigations have shown that substrate or products affect substrate hydrolysis (González et al., 2005; Lokshina et al., 2003; Rao, 2003; Sanders et al., 2003; Vavilin et al., 2001, 2003, 2006; Veeken and Hamelers, 2000). For instance, the $\mathrm{pH}$ of a suspension has been identified as an important inhibitory parameter (Elefsiniotis et al., 1996; Veeken and Hamelers, 2000; Veeken et al., 2000). Additionally, volatile fatty acids (VFA) reduce substrate hydrolysis rates (González et al., 2005; He et al., 2006; Rao, 2003; Vavilin et al., 2006).

Lactate, an intermediate in the anaerobic digestion of organic substrate, is consumed to generate acetate and pro-

\footnotetext{
${ }^{*}$ Corresponding author. Tel./fax: +862165986104.

E-mail address: solidwaste@mail.tongji.edu.cn (P.-J. He).
}

pionate, and is formed under excessively high organic or hydraulic loading, or under loading shocking (Batstone et al., 2002). Lü et al. (2006) demonstrated in fermentation tests with vegetable waste (total solids, TS $=10 \%$ ) that the lactate content could reach $21 \mathrm{~g}^{-1}$ at $\mathrm{pH} 5-9$, accounting for $40-50 \%$ of total organic carbon in acidogenic products. Zhang et al. (2005) noted that lactate from digested kitchen waste could reach a concentration of $8.7 \mathrm{~g}^{-1}$ at $\mathrm{pH} 7$, or to $20.5 \mathrm{~g}^{-1}$ at $\mathrm{pH} 11$. Lactate can reach even higher concentrations in anaerobically digested kitchen wastes herein than were measured by Zhang et al. (2005): concentrations of $30 \mathrm{~g} \mathrm{l}^{-1}$ in anaerobic incubation (Wang et al., 2002) 27 $45 \mathrm{~g}^{-1}$ at $\mathrm{pH} 7$ (Sakai et al., 2004) and $63 \mathrm{~g}^{-1}$ at $\mathrm{pH} 7$ (Zhang et al., 2007b) have been obtained. Ohkouchi and Inoue (2007) claimed that high levels of lactic acid could be produced using carbohydrate-rich stocks. Zhang et al. (2007a) demonstrated the negative effects of accumulated lactic acid $\left(13 \mathrm{~g}^{-1}\right)$ on the performance of the two-phase anaerobic digestion of kitchen wastes.

The inhibition by lactate of the formation of product by fermentative microorganisms has been described (Moon, 1983; Narendranath et al., 2001; van Maris et al., 2004; Warnecke and Gill, 2005). A few works have examined 
the inhibition by lactate of cellulose activity (Iyer and Lee, 1999; Moldes et al., 2001; Takagi, 1984; Yeh et al., 1991). The inhibition by lactate of $\alpha$-amylase and glucoamylase activities has also been observed (Anuradha et al., 1999).

This study elucidates how lactate levels and $\mathrm{pH}$ reduce the rates of the enzymatic hydrolysis of particulate organic substrate. Partial least square (PLS) modeling is employed to investigate the correlation between response variables (such as hydrolysis efficiency) and input factors (such as pH and lactate levels) (Ecke et al., 2003; Jolliffe, 2002; Quinn and Keough, 2002).

\section{Methods}

\subsection{Materials}

Fresh potato, as the test substrate, was cut into cubes of size $2-3 \mathrm{~mm}$ and stored at $4{ }^{\circ} \mathrm{C}$ for $12-24 \mathrm{~h}$ before testing. The potato contained substantial amounts of carbohydrate and some proteins (Table 1).

Enzymes for enzymatic hydrolysis were prepared from sludge that was obtained after secondary treatment at a municipal wastewater treatment plant in Shanghai, China, since no significant difference existed between hydrolytic enzyme activity under anaerobic and aerobic incubations (Goel et al., 1997, 1998). The details of the enzyme extraction procedure have been published elsewhere (He et al., 2006). Table 1 lists the physiochemical characteristics of the enzyme extracts.

\subsection{Hydrolysis test}

This investigation involved three hydrolysis tests, each with a different initial lactic acid concentration. In each test, $20 \mathrm{~g}$ of wet potato was wrapped in gauze bags (80mesh), and hung in bottles with $50 \mathrm{ml}$ of extracted liquors. The extracted liquors employed in the batch I tests were in suspensions at $\mathrm{pH}$ 5-9 (recorded as I-pH 5-I-pH 9), or without $\mathrm{pH}$ control (I-pH unadjusted). Batches II and III tests were performed in a manner similar to batch I tests, but with initial lactate concentrations of 15 and $30 \mathrm{~g}^{-1}$, respectively. Each test was conducted with $50 \mathrm{ml}$ of extracted liquors that were made of $5 \mathrm{ml}$ enzyme extracted

Table 1

Physiochemical characteristics of the experimental materials

\begin{tabular}{lllr}
\hline Potato & \multicolumn{3}{c}{ Enzymatic extracts } \\
\hline TS $\left(\mathrm{g} \mathrm{g}^{-1}-\right.$ wet sample) & 0.18 & $\begin{array}{l}\text { Total organic carbon } \\
\left(\mathrm{mg} \mathrm{l}^{-1}\right)\end{array}$ & 162 \\
$\mathrm{VS}\left(\mathrm{g} \mathrm{g}^{-1}-\mathrm{TS}\right)$ & 0.96 & Total nitrogen $\left(\mathrm{mg} \mathrm{l}^{-1}\right)$ & 50 \\
Carbohydrate $\left(\mathrm{g} \mathrm{g}^{-1}-\mathrm{VS}\right)$ & 0.87 & $\alpha$-Amylase activity $\left(\mathrm{U} \mathrm{l}^{-1}\right)$ & 72.6 \\
Protein $\left(\mathrm{g} \mathrm{g}^{-1}-\mathrm{VS}\right)$ & 0.12 & Proteinase activity $\left(\mathrm{U} \mathrm{l}^{-1}\right)$ & 0.0 \\
Lipid $\left(\mathrm{g} \mathrm{g}^{-1}-\mathrm{VS}\right)$ & 0.005 & & \\
Element C $\left(\mathrm{g} \mathrm{g}^{-1}-\mathrm{VS}\right)$ & 0.41 & & \\
Element N $\left(\mathrm{g} \mathrm{g}^{-1}-\mathrm{VS}\right)$ & 0.14 & & \\
\hline
\end{tabular}

from sludge and $45 \mathrm{ml}$ of $0.1 \mathrm{M}$ phosphate buffer with added lactate.

In the hydrolysis tests, sample bottles were shaken at $100 \mathrm{rpm}$ at $37 \pm 0.2^{\circ} \mathrm{C}$. Extracted liquors were refreshed using fresh liquors at $4,8,12,16,24,32,40,48,60,72$, 96 and $144 \mathrm{~h}$ of testing. With liquor replacement, the $\mathrm{pH}$ and lactate level of suspensions in the tests were periodically recovered, minimizing the effects of the surrounding liquor on hydrolysis efficiencies.

\subsection{Analytical methods}

The collected extracted liquors were filtered using a $0.45 \mu \mathrm{m}$ polyester film, and measured for $\mathrm{pH}$, the concentrations of dissolved carbon, dissolved nitrogen, reducing sugar (RS), and amino acid (AA), and the activities of $\alpha$ amylase and protease. The suspension $\mathrm{pH}$ and oxidationreduction-potential (ORP) were measured using a $\mathrm{pH} /$ ORP meter (OAKTON Instruments, IL, USA). Dissolved carbon and dissolved nitrogen concentrations were measured by first filtering a sample suspension through $0.45 \mu \mathrm{m}$ filter paper followed by making the measurements using a $\mathrm{TN}_{\mathrm{b}} / \mathrm{TC}$ Multi N/C 3000 Analyzer (Analytic Jena AG, Jena, Germany). Reducing sugar concentration was spectrophotometrically determined using the 3,5-dinitrosalicylic acid (DNS) approach (Miller, 1959). The Lowry method was utilized to determine the amino acid content (Lowry et al., 1951). The activities of $\alpha$-amylase were assayed using the Bernfeld method (Bernfeld, 1955). Protease activity was determined using casein as a substrate, according to the method developed by Lowry (McDonald and Chen, 1965).

After $144 \mathrm{~h}$ of testing, residual potato particulates were tested for total solid (TS) content, volatile solid (VS) content, and elemental composition $(\mathrm{C} / \mathrm{H} / \mathrm{N} / \mathrm{S} / \mathrm{O})$. Both TS and VS contents were determined by drying at $70^{\circ} \mathrm{C}$ for $48 \mathrm{~h}$ and at $550{ }^{\circ} \mathrm{C}$ for $6 \mathrm{~h}$, respectively. The elemental composition was measured using a LECO CHNS-932 (LECO Corporation, MI, USA).

\subsection{Data analysis}

Partial least squares modeling (PLS) statistically reveals whether process parameters, such as $\mathrm{pH}$ or lactate, significantly affect the hydrolysis rates of potato samples. The experimental data matrix comprised 234 observations made at different initial $\mathrm{pHs}$, total lactate concentrations, and test times. The initial $\mathrm{pH}(\mathrm{pH}$ initial), final $\mathrm{pH}(\mathrm{pH})$, concentrations of hydronium ions $\left(\mathrm{H}^{+}\right)$, lactic acid (HLA) and lactate ions $\left(\mathrm{LA}^{-}\right)$, total lactate, ORP and test time were the input factors. Cumulative dissolved carbon, cumulative dissolved nitrogen, RS and AA and their production rates $(\mathrm{dC} / \mathrm{d} t, \mathrm{dN} / \mathrm{d} t, \mathrm{dRS} / \mathrm{d} t$, and $\mathrm{dAA} / \mathrm{d} t), \alpha$-amylase activity, protease activity, and fall in amount of VS were the dependent variables in the analysis. Simca-P v.11.0 (Umetrics, Umeå, Sweden) was used for PLS analysis. 


\section{Results and discussion}

\subsection{Particulate hydrolysis}

The hydrolysis efficiencies of potato samples after $144 \mathrm{~h}$ of testing depended on both $\mathrm{pH}$ and lactate level. In batch I tests without acid addition, the fall in VS was maximal at $\mathrm{pH} 7-8$, reaching a level of $61 \%$. The fall in amount of VS declined to $50.8 \%$ at $\mathrm{pH} 9$. In an acidic environment, the fall in VS amount was reduced to $49.6 \%, 40.8 \%$ and $35.5 \%$ at $\mathrm{pH}$ 6,5 and unadjusted $\mathrm{pH}$, respectively. In batch II tests with $15 \mathrm{~g}^{-1}$ lactate, the VS reduction was maximal at $\mathrm{pH} 8$ $(42.9 \%)$ and $\mathrm{pH} 9(37.1 \%)$. Under neutral conditions, the hydrolyzed VS was $29.1 \%$ at $\mathrm{pH}$ 7. In an acidic environment, the fall in VS amount was $27.7 \%, 18.6 \%$ and $17 \%$ at $\mathrm{pH} 6,5$ and unadjusted $\mathrm{pH}$, respectively. In batch III tests with $30 \mathrm{~g}^{-1}$ lactate, the VS reduction was significantly reduced to $16.7 \% \pm 2.7 \%$ and was independent of $\mathrm{pH}$. Externally dose acetate (He et al., 2006) reduced the fall in VS amount

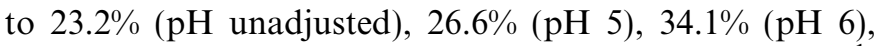
$47.3 \%(\mathrm{pH} 7), 43.1 \%(\mathrm{pH} 8)$ and $42.7 \%(\mathrm{pH} 9)$ at $20 \mathrm{~g}^{-1}$. Accordingly, lactate was more suppressive than acetate.

The amounts of hydrolyzed dissolved carbon in batch I tests (Fig. 1a) were higher than those in batch II (Fig. 1b) and batch III (Fig. 1c) tests over the $\mathrm{pH}$ range. The cumulative amount of dissolved carbon in batch I tests followed the order $\mathrm{pH} 7-8>\mathrm{pH} 9>\mathrm{pH} \quad 6>\mathrm{pH} 5>$ unadjusted $\mathrm{pH}$, which is consistent with order of the effects of $\mathrm{pH}$ on the drop in the amount of VS. The cumulative amount of dissolved carbon in batch II tests followed an order similar to that in batch I, except that the efficiency at $\mathrm{pH} 7$ was close to that at $\mathrm{pH}$ 8-9. The cumulative amount of dissolved carbon in batch I reached a plateau at $40-80 \mathrm{~h}$, whereas that in batch II reached a lower plateau after $120 \mathrm{~h}$. The cumulative amounts of dissolved carbon were lower for batch III than for batches I and II.

The cumulative amounts of dissolved nitrogen in batches I-III tests were also analyzed (Fig. 2). The presence of high levels of lactate enhanced the hydrolysis of substrate that contained nitrogen. The plateau values for batches I and II were $229 \pm 72 \mathrm{mg} \mathrm{N}^{-1}$, and that for batch III was $1010 \pm 365 \mathrm{mg} \mathrm{N}^{-1}$. Large fluctuations were present in the data from the samples, suggesting intrinsic differences among the tested samples rather than $\mathrm{pH}$-controlling protein extraction efficiencies.

The activities of $\alpha$-amylase during $144 \mathrm{~h}$ of tests were highest in batch I at $\mathrm{pH} 7\left(189 \pm 49 \mathrm{Ul}^{-1}\right)$ and $\mathrm{pH} 8$ $\left(171 \pm 49 \mathrm{U}^{-1}\right)$, followed by $\mathrm{pH} 9\left(115 \pm 39 \mathrm{U}^{-1}\right), \mathrm{pH}$ $6\left(66 \pm 32 \mathrm{U}^{-1}\right)$ and $\mathrm{pH} 5\left(33 \pm 12 \mathrm{U}^{-1}\right)$. In batch II tests with $15 \mathrm{~g}^{-1}$ lactate, the activities of $\alpha$-amylase were highest at $\mathrm{pH} 8\left(102 \pm 49 \mathrm{U}^{-1}\right)$, followed by $\mathrm{pH} 9$ $\left(69 \pm 25 \mathrm{U} \mathrm{l}^{-1}\right), \quad \mathrm{pH} \quad 7 \quad\left(69 \pm 30 \mathrm{U} \mathrm{l}^{-1}\right), \quad \mathrm{pH} \quad 5$ $\left(62 \pm 17 \mathrm{U}^{-1}\right)$ and pH $6\left(46 \pm 10 \mathrm{U}^{-1}\right)$. In batch III tests with $30 \mathrm{~g}^{-1}$ lactate, the amylase activities were overall lower than $50 \mathrm{U} \mathrm{l}^{-1}\left(\mathrm{pH} 5,39 \pm 10 \mathrm{Ul}^{-1} ; \mathrm{pH}\right.$ 6,

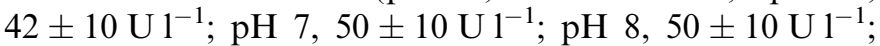
$\left.\mathrm{pH} 9,45 \pm 10 \mathrm{U}^{-1}\right)$.
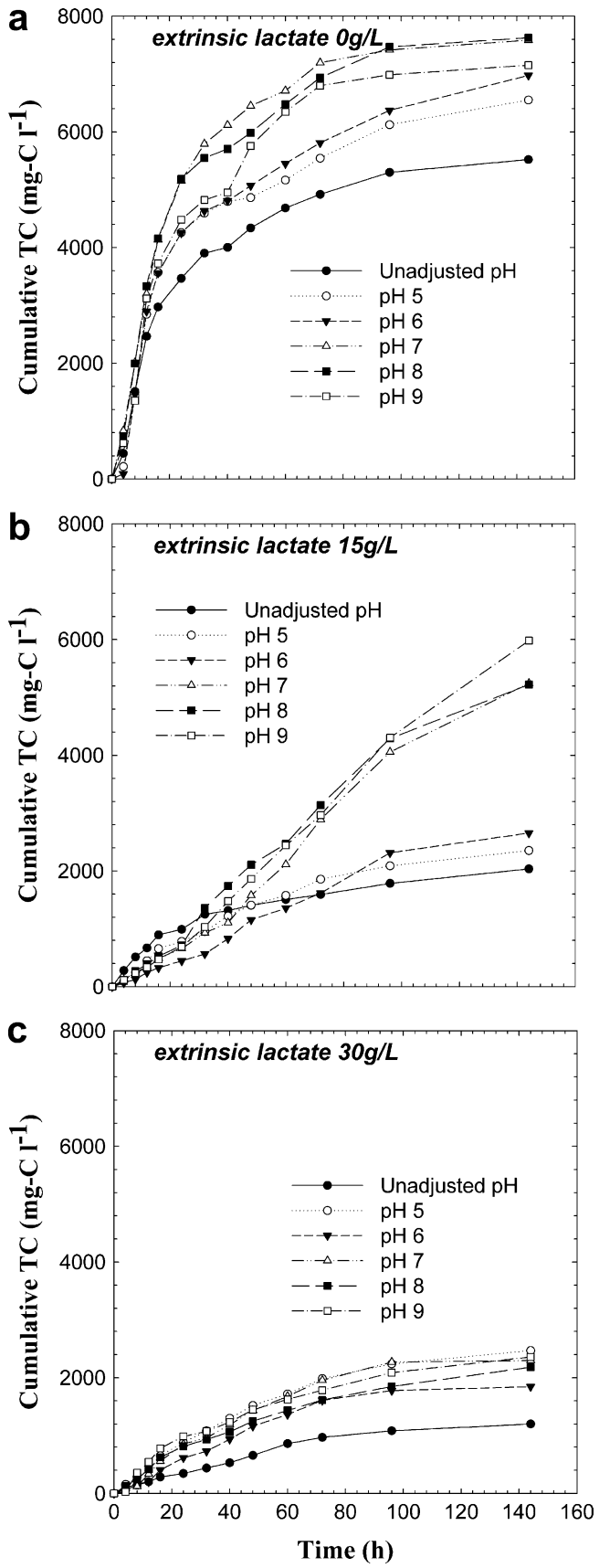

Fig. 1. Effect of $\mathrm{pH}$ and lactate levels in extracted liquors on cumulative amounts of dissolved carbon.

The activities of protease during $144 \mathrm{~h}$ of tests were highest in batch III with $30 \mathrm{gl}^{-1}$ lactate $(\mathrm{pH} 5$, $8726 \pm 5527 \mathrm{U}^{-1} ;$ pH $6, \quad 7421 \pm 3238 \mathrm{U} \mathrm{l}^{-1} ;$ pH 7, $6568 \pm 3056 \mathrm{U}^{-1} ;$ pH $8,7421 \pm 3646 \mathrm{U}^{-1} ;$ pH 9 , $5930 \pm 3559{\mathrm{U} 1^{-1}}^{-}$, decreasing as the lactate dose fell in batch II and batch I: the results were $(\mathrm{pH} 5$, $5516 \pm 3836 \mathrm{U} \mathrm{l}^{-1} ;$ pH $6, \quad 5254 \pm 3465 \mathrm{U} \mathrm{l}^{-1} ;$ pH 7 , $4649 \pm 2558 \mathrm{U}^{-1} ;$ pH $8,6016 \pm 3663 \mathrm{U}^{-1} ;$ pH 9, $\left.4943 \pm 3159 \mathrm{U}^{-1}\right)$ and $\left(\mathrm{pH} 5,1743 \pm 989 \mathrm{U}^{-1} ; \mathrm{pH} \mathrm{6}\right.$, $1981 \pm 1019 \mathrm{U}^{-1} ;$ pH $7, \quad 2117 \pm 1604 \mathrm{Ul}^{-1} ; \mathrm{pH} \quad 8$, $1903 \pm 1514 \mathrm{U}^{-1} ;$ pH 9, $\left.7347 \pm 3559 \mathrm{U}^{-1}\right)$, respectively. 

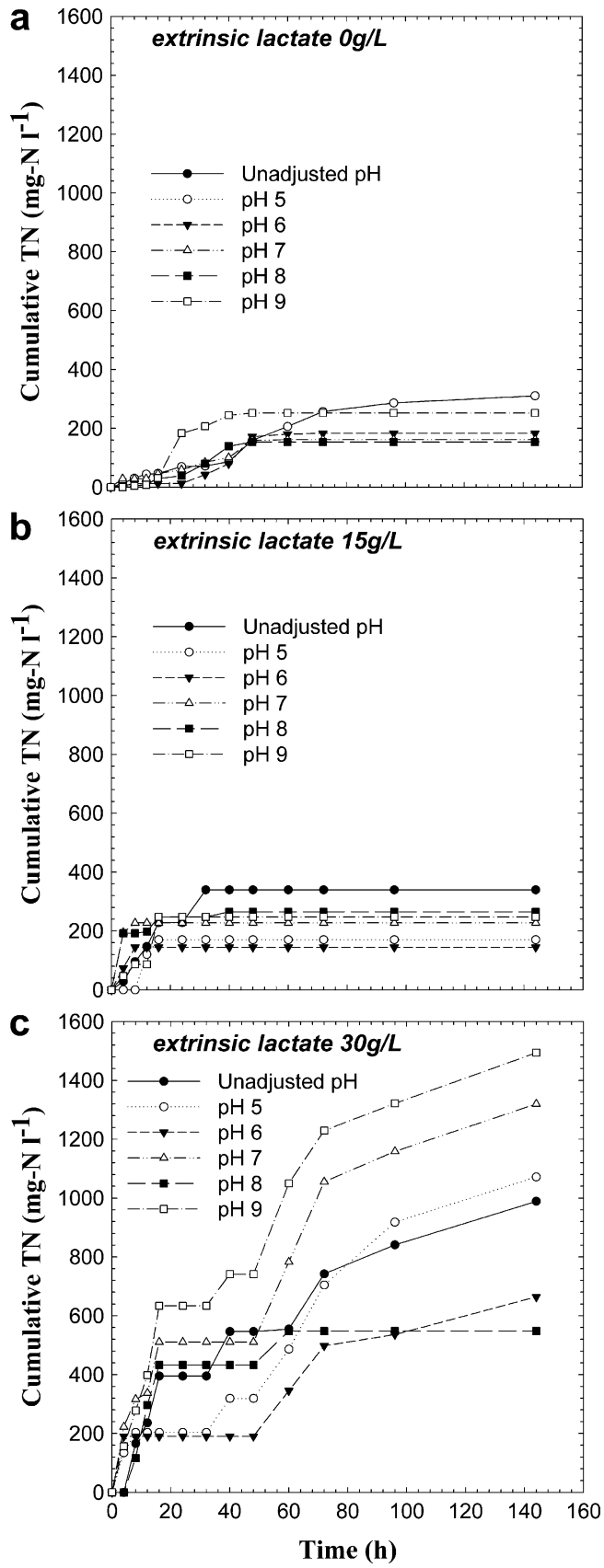

Fig. 2. Effect of pH and lactate levels in extracted liquors on cumulative amounts of dissolved nitrogen.

According to the data fluctuation, the activities of these enzymes generally correlated with hydrolysis efficiencies (Figs. 1 and 2). Lactate suppressed carbon hydrolysis particularly in an acidic environment. Conversely, the presence of lactate promoted nitrogen hydrolysis, and was weakly correlated with suspension $\mathrm{pH}$.

\subsection{Statistical analysis}

The PLS modeling of carbohydrate hydrolysis demonstrated that three principal components, PC1, PC2 and PC3, accounted for $21.3 \%, 12.7 \%$ and $7.0 \%$ of the variation in the data, respectively. The presented model revealed unresolved variability associated with noise, the impact of factors that were not considered, or the setting of certain parameters to constants. The loading plot (Fig. 3a) indicates that the hydrolysis of carbohydrate depended substantially on $\mathrm{pH}$, lactic acid concentration, ORP and test duration. The loading of responses was high in PC1 ( $21.3 \%$ of the data variation), and the total lactate and dissociated lactate $\left(\mathrm{LA}^{-}\right)$loadings were higher in $\mathrm{PC} 1$ than any of the factors considered, suggesting that lactic acid most strongly affected the carbohydrate hydrolysis rate. The score contribution plot (Fig. 3b) also demonstrates that total lactate and dissociated lactate had higher scores than $\mathrm{pH}$ and HLA. Hence, the suppressive effects of carbon hydrolysis examined in this work should be the result of the chemical nature of lactate, rather than the reduced $\mathrm{pH}$.

The PLS model of protein hydrolysis generated three principal components, which explained $19.4 \%, 8.6 \%$ and $1.7 \%$ of the data variation, respectively, or $29.9 \%$ together. The loading plot (Fig. 4a) revealed that the effect of $\mathrm{pH}$ was
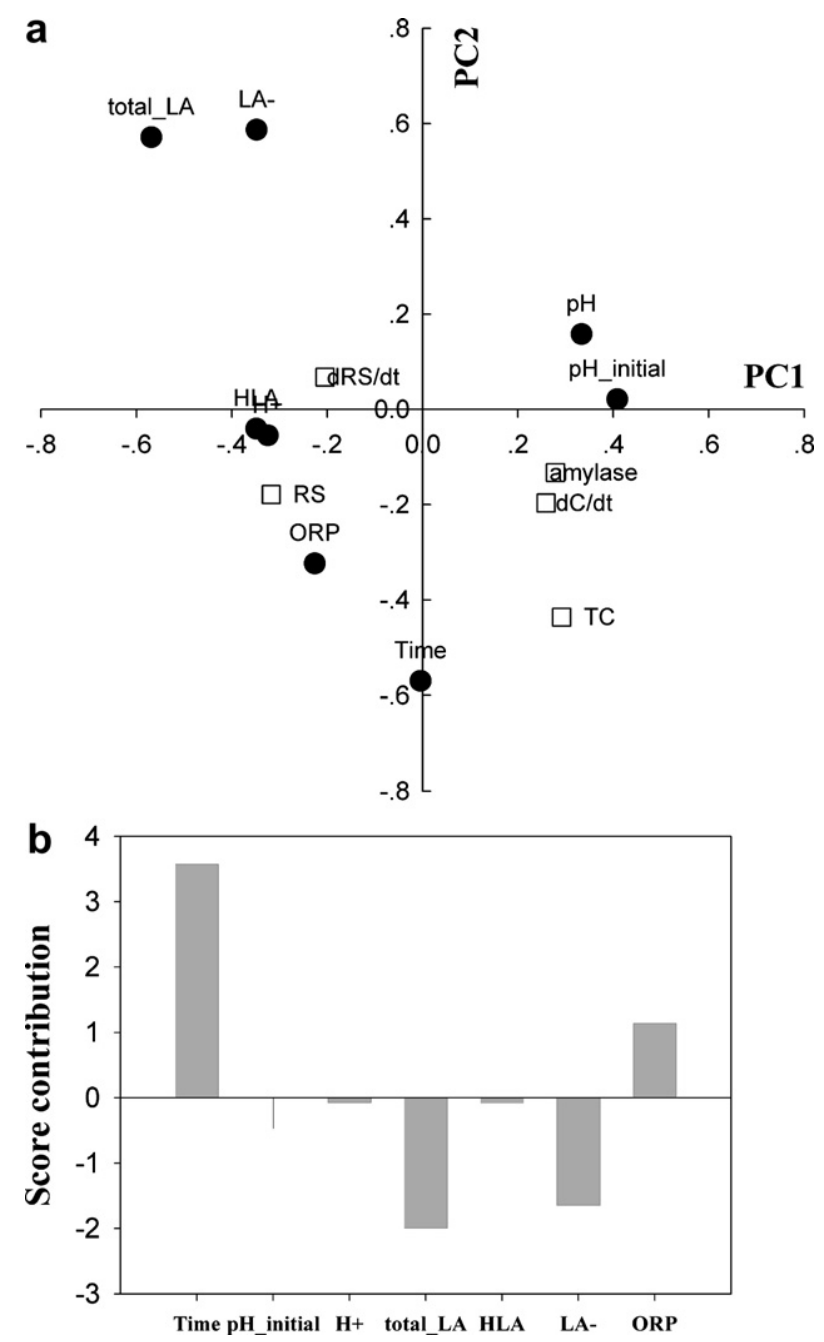

Fig. 3. Partial least squares analysis for carbohydrate hydrolysis. (a) Loadings plot of first and second principal components: $\bullet$ factors; $\square$ responses. (b) Score contribution of variables. 

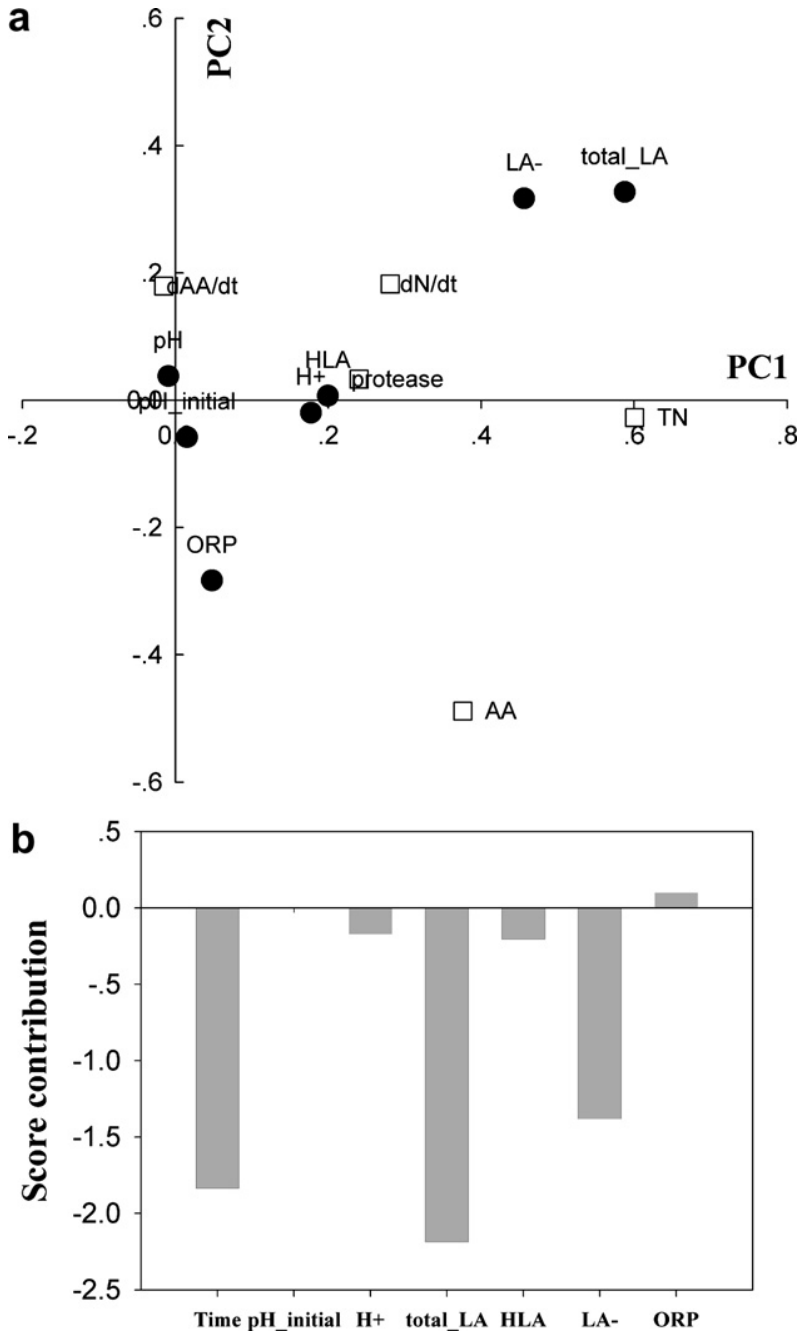

Fig. 4. Partial least squares analysis for protein hydrolysis. (a) Loadings plot of first and second principal components: factors; $\square$ responses. (b) Score contribution of variables.

minor in PC1 and PC2, whereas total lactate and dissociated lactate were more strongly weighted than $\mathrm{H}^{+}$and HLA, revealing that lactate rather than $\mathrm{pH}$ determined the hydrolysis of protein. Furthermore, lactate- and nitrogen-related parameters (TN, AA, and protease) located on the same side of PC1. Accordingly, the protein hydrolysis efficiency was positively correlated with the lactate concentrations. The score plot also verified this correlation (Fig. 4b).

The PLS analysis results demonstrated that $\mathrm{pH}$ and lactate differently influenced the hydrolysis rates of carbohydrates and proteins. Both $\mathrm{pH}$ and lactate affected carbohydrate hydrolysis, and the lactate was dominant and more inhibitory. Conversely, lactate and not $\mathrm{pH}$ enhanced the hydrolysis of protein.

When only hydrolyzed VS was considered as a response factor, PLS modeling revealed two principal components, which were responsible for $75.5 \%$ and $7.4 \%$ of the data variation, respectively, or a total $82.9 \%$ of the data variation (Fig. 5). Total lactate and dissociated lactate more strongly

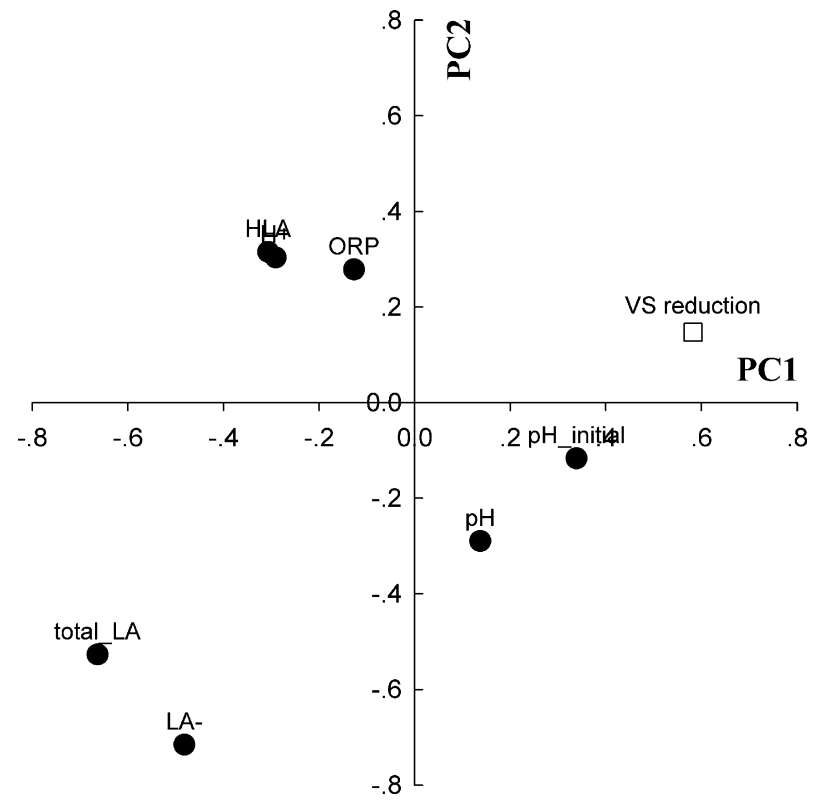

Fig. 5. Partial least squares analysis for volatile solid hydrolysis: factors; $\square$ responses.

reduced the amount of VS than did $\mathrm{pH}$ and the undissociated lactate. Lactate was negatively correlated and $\mathrm{pH}$ was positively correlated with VS reduction.

\subsection{Inhibitory hydrolysis with lactate or acetate}

He et al. (2006) demonstrated the inhibitive effects of externally dosed acetate on the hydrolysis of organic particulates. With $20 \mathrm{~g}^{-1}$ acetate, the VS reduction of potato samples was higher under alkaline than under acidic conditions; the reduction ratio was $42-47 \%$ at $\mathrm{pH} 7-9$ and 26 $34 \%$ at $\mathrm{pH} 5-6$. Accordingly, the presence of lactate or acetate suppresses the rate of hydrolysis of polysacchariderich, potato samples. In contrast with the conclusions drawn for lactate in Sections 3.1 and 3.2, He et al. (2006) concluded that induced $\mathrm{pH}$ changes more strongly inhibited carbohydrate hydrolysis than dose acetate. Lactate $\left(\mathrm{p} K_{\mathrm{a}}=3.86\right.$ at $25^{\circ} \mathrm{C}$ ) inhibited the hydrolysis efficiency of tested potato samples more than did acetate $\left(\mathrm{p} K_{\mathrm{a}}=4.74\right.$ at $25^{\circ} \mathrm{C}$ ) on an equal weight or equal molar basis. Additionally, acetate inhibits and lactate enhances protein hydrolysis. Hence, the effects of lactate and acetate as intermediates during the anaerobic digestion of organic substrates, in inhibiting substrate hydrolysis differ.

\section{Conclusions}

The study suggested that the suppression of carbohydrate hydrolysis by 15 or $30 \mathrm{~g}^{-1}$ lactate was stronger than that by acetate or by a change in $\mathrm{pH}$. Lactate stimulated protein hydrolysis and the effect of $\mathrm{pH}$ on protein hydrolysis was insignificant. Accordingly, the influence of lactate on carbohydrate or protein hydrolysis was associated primarily with the presence of lactate species, rather than 
the corresponding fall in $\mathrm{pH}$. Since lactate can be produced in significant amounts during the fermentation of organic waste with a high solid content, the bi-directional role of lactate in hydrolysis should be regarded as non-trivial in comprehensive modeling, such as that in ADM No. 1.

\section{Acknowledgements}

This work was financially supported by the National Sci. \& Tech. Supporting Program of China (2006BAJ04A06), Key Project of Chinese Ministry of Education (107122), Shanghai-Rhone Alpes Region International Scientific Research Cooperation Fund (06SR07105) and Program for Young Excellent Talents in Tongji University (2006KJ032).

\section{References}

Anuradha, R., Suresh, A.K., Venkatesh, K.V., 1999. Simultaneous saccharification and fermentation of starch to lactic acid. Process Biochem. 35 (3-4), 367-375.

Batstone, D., Keller, J., Angelidaki, I., Kalyuzhnyi, S.V., Pavlostathis, S.G., Rozzi, A., Sanders, W.T.M., Siegrist, H., Vavilin, V.A., 2002. Anaerobic Digestion Model No. 1 (ADM1), IWA Task Group for Mathematical Modelling of Anaerobic Digestion Processes. IWA Publishing, London.

Bernfeld, P., 1955. Amylase $\alpha$ and $\beta$. Methods Enzymol. 1, 149-151.

Ecke, H., Menad, N., Lagerkvist, A., 2003. Carbonation of municipal solid waste incineration fly ash and the impact on metal mobility. J. Environ. Eng. ASCE 129 (5), 435-440.

Elefsiniotis, P.T., Wareham, D.G., Oldham, W.K., 1996. Particulate organic carbon solubilization in an acid-phase upflow anaerobic sludge blanket system. Environ. Sci. Technol. 30 (5), 1508-1514.

Goel, R., Mino, T., Satoh, H., Matsuo, T., 1997. Effect of electron acceptor conditions on hydrolytic enzyme synthesis in bacterial cultures. Water Res. 31 (10), 2597-2603.

Goel, R., Mino, T., Satoh, H., Matsuo, T., 1998. Comparison of hydrolytic enzyme systems in pure culture and activated sludge under different electron acceptor conditions. Water Sci. Technol. 37 (4-5), 335-343.

González, G., Urrutia, H., Roeckel, M., Aspé, E., 2005. Protein hydrolysis under anaerobic, saline conditions in presence of acetic acid. J. Chem. Technol. Biot. 80 (2), 151-157.

He, P.J., Lü, F., Shao, L.M., Pan, X.J., Lee, D.J., 2006. Enzymatic hydrolysis of polysaccharide-rich particulate organic waste. Biotechnol. Bioeng. 93 (6), 1145-1151.

Iyer, P.V., Lee, Y.Y., 1999. Product inhibition in simultaneous saccharification and fermentation of cellulose into lactic acid. Biotechnol. Lett. 21 (5), 371-373.

Jolliffe, I.T., 2002. Principal Component Analysis, second ed. Springer, New York.

Lokshina, L.Y., Vavilin, V.A., Salminenm, E., Rintala, J., 2003. Modeling of anaerobic degradation of solid slaughterhouse waste - inhibition effects of long-chain fatty acids or ammonia. Appl. Biochem. Biotechnol. 109 (1-3), 15-32.

Lowry, O.H., Rosebrough, N.J., Lewis Farr, A., Randall, R., 1951. Protein measurements with the folin phenol reagent. J. Biol. Chem. 193 (1), 265-275.

Lü, F., He, P.J., Shao, L.M., Chen, H.H., 2006. Effect of pH value on fermentation pathways of biodegradable organic waste. Environ. Sci. 27 (5), 991-997 (in Chinese).

Mata-Alvarez, J., 2003. Fundamentals of the anaerobic digestion process. In: Mata-Alvarez, J. (Ed.), Biomethanization of the Organic Fraction of Municipal Solid Wastes. IWA Publishing, London, pp. 1-20.
McDonald, C.E., Chen, L.L., 1965. Lowry modification of the folin reagent for determination of proteinase activity. Anal. Biochem. 10 (1), 175-177.

Miller, G.L., 1959. Use of dinitrosalicylic acid reagent for determination of reducing sugar. Anal. Chem. 31 (3), 426-428.

Miron, Y., Zeeman, G., Lier, J.B.V., Lettinga, G., 2000. The role of sludge retention time in the hydrolysis and acidification of lipids, carbohydrates and proteins during digestion of primary sludge in CSTR systems. Water Res. 34 (5), 1705-1713.

Moldes, A.B., Alonso, J.L., Parajo, J.C., 2001. Strategies to improve the bioconversion of processed wood into lactic acid by simultaneous saccharification and fermentation. J. Chem. Technol. Biot. 76 (3), 279 284.

Moon, N.J., 1983. Inhibition of the growth of acid tolerant yeasts by acetate, lactate and propionate and their synergistic mixtures. J. Appl. Bacteriol. 55 (3), 453-460.

Narendranath, N.V., Thomas, K.C., Ingledew, W.M., 2001. Acetic acid and lactic acid inhibition of growth of Saccharomyces cerevisiae by different mechanisms. J. Am. Soc. Brew. Chem. 59 (4), 187-194.

Ohkouchi, Y., Inoue, Y., 2007. Impact of chemical components of organic wastes on $1(+)$-lactic acid production. Bioresource Technol. 98 (3), 546-553.

Quinn, G.P., Keough, M.J., 2002. Experimental Design and Data Analysis for Biologists. Cambridge University Press, London.

Rao, C.S., 2003. The role of water in the control of enzyme functionality at interfaces. Ph.D. Thesis, University of Wisconsin - Madison, Madison, WI, USA

Sakai, K., Mori, M., Fujii, A., Iwami, Y., Chukeatirote, E., Shirai, Y., 2004. Fluorescent in situ hybridization analysis of open lactic acid fermentation of kitchen refuse using rRNA-targeted oligonucleotide probes. J. Biosci. Bioeng. 98 (1), 48-56.

Sanders, W.T.M., Veeken, A.H.M., Zeeman, G., van Lier, J.B., 2003. Analysis and optimization of the anaerobic digestion of the organic fraction of municipal solid waste. In: Mata-Alvarez, J. (Ed.), Biomethanization of the Organic Fraction of Municipal Solid Wastes. IWA Publishing, London, pp. 63-90.

Takagi, M., 1984. Inhibition of cellulase by fermentation products. Biotechnol. Bioeng. 26 (12), 1506-1507.

van Maris, A.J.A., Konings, W.N., van Dijken, J.P., Pronka, J.T., 2004. Microbial export of lactic and 3-hydroxypropanoic acid: implications for industrial fermentation processes. Metab. Eng. 6 (4), 245-255.

Vavilin, V.A., Rytov, S.V., Lokshina, L.Y., 1996. A description of hydrolysis kinetics in anaerobic degradation of particulate organic matter. Bioresource Technol. 56 (2-3), 229-237.

Vavilin, V.A., Shchelkanov, M.Y., Lokshina, L.Y., 2001. The effect of fatty acid diffusion in leachate on the propagation of concentration waves in the process of municipal solid waste decomposition. Water Res. 28 (6), 691-697.

Vavilin, V.A., Rytov, S.V., Lokshina, L.Y., Pavlostathis, S.G., Barlaz, M.A., 2003. Distributed model of solid waste anaerobic digestion: effects of leachate recirculation and $\mathrm{pH}$ adjustment. Biotechnol. Bioeng. 81 (1), 66-73.

Vavilin, V.A., Jonsson, S., Ejlertson, J., Svensson, B.H., 2006. Modelling MSW decomposition under landfill conditions considering hydrolytic and methanogenic inhibition. Biodegradation 17 (5), 1572-9729.

Veeken, A., Hamelers, B., 2000. Effect of substrate-seed mixing and leachate recirculation on solid state digestion of biowaste. Water Sci. Technol. 41 (3), 255-262.

Veeken, A., Kalyuzhnyi, S., Scharff, H., Hamelers, B., 2000. Effect of pH and VFA on hydrolysis of organic solid waste. J. Environ. Eng. ASCE 126 (12), 1076-1081.

Wang, Q., Narita, J.Y., Xie, W., Ohsumi, Y., Kusano, K., Shirai, Y., Ogawa, H.I., 2002. Effects of anaerobic/aerobic incubation and storage temperature on preservation and deodorization of kitchen garbage. Bioresource Technol. 84 (3), 213-220.

Warnecke, T., Gill, R.T., 2005. Organic acid toxicity, tolerance, and production in Escherichia coli biorefining applications. Microbial Cell Factories 4 (1), 25-32. 
Yeh, P.L.H., Bajpai, R.K., Iannotti, E.L., 1991. An improved kinetic model for lactic acid fermentation. J. Ferment. Bioeng. 71 (1), 75-77.

Zhang, B., Zhang, L.L., Zhang, S.C., Shi, H.Z., Cai, W.M., 2005. The Influence of $\mathrm{pH}$ on hydrolysis and acidogenesis of kitchen wastes in two-phase anaerobic digestion. Environ. Technol. 26 (3), 329-340.
Zhang, B., Cai, W.M., He, P.J., 2007a. The influence of lactic acid on the two-phase anaerobic digestion of kitchen wastes. J. Environ. Sci. China 19 (2), 244-249.

Zhang, B., He, P.J., Ye, N.F., Shao, L.M., 2007b. Enhanced isomer purity of lactic acid from the non-sterile fermentation of kitchen wastes. Bioresource Technol. doi:10.1016/j.biortech.2007.01.010. 